\title{
PRODUKSI BIODIESEL DARI MINYAK KACANG TANAH DARI PEDAGANG SATE MENGGUNAKAN 3 TAHAPAN PROSES DAN PERBEDAAN KONSENTRASI KATALIS $\mathrm{KOH}$
}

\section{BIODIESEL PRODUCTION OF PEANUT OIL TRADERS SATE OF USING THE 3 STAGES OF PROCESS AND A CATALYST CONCENTRATION DIFFERENCE KOH}

\author{
Achmad Faisal Faputri ${ }^{1)}$, Indah Agus Setiorini ${ }^{2)}$ \\ ${ }^{1,2)}$ Program Studi Teknik Pengolahan Migas Politeknik Akamigas Palembang, 30257, Indonesia \\ Corresponding Author E-mail: achmadfaisal@pap.ac.id dan indahagussetiorini_sukarman@yahoo.co.id
}

\begin{abstract}
Vegetable oil is one alternative that can be used as raw material for biodiesel production. The content of vegetable oils are mostly found in peanut seeds. The composition contained in peanut seeds is $40-60 \mathrm{wt} \%$ vegetable oil, $25-30 \mathrm{wt} \%$ crude protein, and water content, fiber, and ash by $10-25 \% \mathrm{wt}$ in meat peanut seeds free from shell. In this study, peanut oil was taken from satay traders because this oil caused an unpleasant odor in peanut satay seasoning so it needed to be removed by satay traders. The research is expected to obtain optimal conditions from the comparison of the concentration of the $\mathrm{KOH}$ catalyst in the transesterification reaction of peanut oil used with methanol to produce optimal biodiesel in accordance with SNI.. The research method of biodiesel production from peanut seeds is carried out by preparing peanut seeds obtained from the byproduct of making seasonings for the process of adsorption of peanuts using activated charcoal then esterification and transesterification and purification of biodiesel from impurities. The results of the analysis of Peanut Free Fatty Acid before treatment were 1,28\% after adsorption with activated charcoal to $1,09 \%$ and after esterification was $0,41 \%$. The results of the analysis of biodiesel production with variable catalyst concentration $\mathrm{KOH}(0,5 \% \mathrm{wt}, 1 \% \mathrm{wt}, 1,5 \% \mathrm{wt}$, and $2,0 \% \mathrm{wt})$ at a ratio of $1: 3$ (oil: methanol), constant temperature $60^{\circ} \mathrm{C}$, and a constant time of 60 minutes obtained optimal biodiesel results at $2 \%$ wt $\mathrm{KOH}$ concentration with yield of $440 \mathrm{ml}$ biodiesel, density $0,870 \mathrm{~g} / \mathrm{cm}^{3}$, flash point $122{ }^{\circ} \mathrm{C}$, pour point $15,55^{\circ} \mathrm{C}$, Copper strip corrosion 1 , distillation temperature $90 \%$ by $92 \%$ at a maximum temperature of $360 \mathrm{oC}$, water and sediment $0,05 \%$ vol.
\end{abstract}

Keywords: Biodiesel, Adsorption, Esterification, Transesterification, Active Charcoal.

\begin{abstract}
Abstrak: Pembuatan biodiesel salah satu bahan baku yang digunakan yaitu minyak nabati. Kacang tanah memiliki kandungan minyak nabati yang cukup besar. Kandungan minyak nabati yang terdapat pada kacang tanah berkisar antara 40-60\% wt, selain itu kandungan pada kacang tanah yaitu protein kasar 25-30\%wt, serta kadar air, serat, dan abu sebesar 10-25\%wt dalam daging biji kacang tanah yang bebas dari cangkangnya. Minyak kacang tanah pada penelitian ini diambil dari pedagang sate karena minyak ini menyebabkan bau yang tidak enak pada bumbu kacang sate sehingga perlu dihilangkan oleh pedagang sate. Penelitian ini diharapkan mendapatkan kondisi yang optimal dengan menggunakan 3 tahapan, adsopsi, esterifikasi dan transesterifikasi minyak kacang tanah untuk menghasilkan biodiesel yang optimal sesuai dengan SNI. Metode penelitian pembuatan biodiesel dari biji kacang tanah dilakukan dengan cara preparasi biji kacang tanah yang didapatkan dari hasil samping pembuatan bumbu kacang dengan proses adsorpsi menggunakan arang yang diaktivasi selanjutnya proses esterifikasi dan transesterifikasi serta tahapan pemurnian biodiesel dari pengotor. Hasil analisa Asam Lemak Bebas kacang tanah sebelum treatment sebesar 1,28 \% setelah dilakukan adsorpsi dengan arang aktif menjadi 1,09\% dan setelah di esterifikasi adalah 0,41 \%. Hasil analisa pada produksi biodiesel dengan konsentrasi katalis $\mathrm{KOH} 2,0 \%$ wt pada rasio $1: 3$ (minyak : metanol), suhu konstan $60{ }^{\circ} \mathrm{C}$, dan waktu konstan 60 menit diperoleh hasil biodiesel optimal pada konsentrasi katalis $\mathrm{KOH} 2 \%$ wt dengan rendemen biodiesel $440 \mathrm{ml}$, densitas $0,870 \mathrm{~g} / \mathrm{cm}^{3}$, flash point $122{ }^{\circ} \mathrm{C}$, pour point $15,55{ }^{\circ} \mathrm{C}$, Copper Strip Corrosion 1 , volume Temperature Destilasi $90 \%$ sebesar $92 \%$ pada temperatur maksimal $360{ }^{\circ} \mathrm{C}$, air dan sedimen $0,05 \%$ vol.
\end{abstract} Kata Kunci : Biodiesel, Esterifikasi,Transesterifikasi, Adsorpsi, Arang Aktif.

\section{PENDAHULUAN}

Bahan bakar minyak bumi merupakan sumber energi utama yang banyak digunakan untuk kepentingan manusia diberbagai negara. Kebutuhan bahan bakar ini selalu meningkat, seiring dengan penggunaannya di bidang industri maupun transportasi. Indonesia pada saat ini telah menjadi pengimpor minyak mentah, sehingga berdampak pada devisa negara. Langkah - langkah yang dilakukan pemerintah untuk menekan impor minyak 
mentah dengan mengeluarkan kebijakan bahan bakar biodiesel B20. Penunjukkan angka setelah huruf B merupakan metode yang diterima secara universal untuk menunjukkan campuran biodiesel dan petrodiesel. B20 adalah biodiesel $20 \%$ dan petrodiesel $80 \%{ }^{[1]}$. biodiesel merupakan monoalkil ester dari minyak nabati atau lemak hewan mengalami reaksi kimia disebut dengan proses transesterifikasi $^{[2]}$. Minyak jelantah dapat diubah menjadi biodiesel (alkil ester) melalui proses transesterifikasi dikarenakan minyak jelantah yang mengandung trigliserida apabila direaksikan dengan alkohol sehingga dapat terkonversi menjadi biodiesel dan hasil samping berupa gliserol dengan bantuan katalis basa kuat. Faktor yang mempengaruhi proses transesterifikasi minyak nabati asam lemak jenuh menjadi biodisel, yaitu: pemilihan katalis, rasio alkohol terhadap minyak nabati, kemurnian bahan baku, dan suhu operasi produksi serta lamanya reaksi. Keunggulan katalis basa homogen dapat dijalankan pada kondisi dan tekanan rendah serta waktu yang cepat namun kelemahan proses ini kecenderungannya memiliki kadar asam lemak bebas rendah ${ }^{[3]}$. pemanfaatan minyak nabati pada biji kacang tanah sebagai bahan baku untuk pembuatan biodiesel ini mengandung 40-60 \% wt minyak nabati, protein kasar 25 $30 \%$ wt, serta kadar air, serat, dan abu sebesar 10-25\% $\mathrm{wt}^{[4]}$. Minyak jelantah dari bahan baku berupa minyak kacang tanah yang dihasilkan oleh pedagang sate menggunakan proses hidrolisa sehingga tidak banyak mengalami penguraian molekul. Minyak kacang tanah biasanya hanya digunakan sebagian kecil untuk menggoreng jika dibandingkan dengan Minyak jelantah yang digunakan rumah tangga maka mengandung asam lemak bebas yang tinggi dibandingkan dengan minyak kacang tanah dari hasil samping pedagang sate hal ini disebabkan minyak jelantah telah mengalami penguraian molekul-molekul, sehingga dapat pecahnya ikatan trigliserida menjadi gliserol dan kandungan asam lemak bebas tinggi. Proses pembuatan biodiesel menggunakan bahan baku minyak kacang tanah hasil samping pedagang sate diinginkan dapat menghasilkan biodiesel yang sesuai dengan Standar Nasional Indonesia (SNI), menghasilkan proses pembuatan biodisel yang optimal dan memberikan nilai tambah bagi pedagang sate untuk memproduksi biodiesel.

\section{TEORI DASAR}

Secara umum diketahui bahwa minyak nabati dan lemak hewan telah diteliti sebagai bahan bakar diesel baik sebelum krisis energi tahun 1970-an dan awal 1980-an memicu minat baru dalam bahan bakar alternatif. Hal ini juga diketahui bahwa Rudolf Diesel (18581913), penemu mesin diesel, memiliki beberapa kepentingan dalam bahan bakar ini [5]. Minyak nabati adalah senyawa organik yang terdapat di alam dan tak larut dalam air, tetapi dapat larut dengan pelarut non-polar seperti senyawa hidrokarbon. Minyak nabati maupun lemak hewani memiliki komposisi yaitu senyawa gliserida dan asam lemak dengan rantai $\mathrm{C}$-nya yang panjang. Asam lemak merupakan asam karboksilat yang diperoleh dari hidrolisis suatu lemak dan minyak yang umumnya memiliki rantai karbon panjang dan tak bercabang. Gliserida merupakan ester dari gliserol. Gliserida terdiri dari monogliserida, digliserida, dan trigliserida tergantung dari jumlah asam lemak yang terikat pada gliserol. Biodiesel adalah monoalkil ester yang merupakan bahan bakar ramah terhadap lingkungan. Biodiesel tidak mengandung berbahaya seperti $\mathrm{Pb}$, bersifat biodegradable, emisi gas buangnya juga lebih rendah dibandingkan emisi bahan bakar diesel. Biodiesel memiliki efek pelumasan yang tinggi sehingga dapat memperpanjang umur mesin dan memiliki angka setana yang tinggi ( $>50)^{[6]}$. Alkohol merupakan komponen utama yang diperlukan dalam memproduksi biodiesel, alkohol diperlukan dalam jumlah berlebih, baik dalam reaksi esterifikasi maupun reaksi transesterifikasi ${ }^{[3]}$. Jenis alkohol yang banyak digunakan yaitu metanol dengan kelebihannya lebih mudah bereaksi karena rantai atom $\mathrm{C}$ yang pendek dan harganya relative lebih murah dibandingkan jenis alkohol yang lain. Minyak kacang tanah 
bekas bisa digunakan sebagai bahan baku dalam proses pembuatan biodiesel. Minyak kacang tanah bekas mengandung asam lemak bebas (Free Fatty Acid, FFA) yang dihasilkan dari hidrolisis pada saat pengambilan minyak dari biji kacang tanah dan teroksidasi pada saat penyimpanan. Asam lemak bebas tersebut dihilangkan dengan mereaksikan asam lemak bebas dengan methanol atau alkohol menggunakan bantuan katalis asam seperti asam sulfat. Reaksi ini dikenal dengan reaksi esterifikasi.

Persamaan reaksi esterifikasi asam lemak bebas dan methanol.

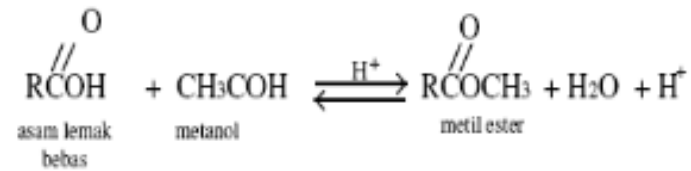

Reaksi transesterifikasi didefinisikan sebagai reaksi antara alcohol dan trigliserida membentuk alkil ester dan gliserol. Alkil ester inilah yang disebut dengan biodiesel.

Persamaan reaksi transesterifikasi

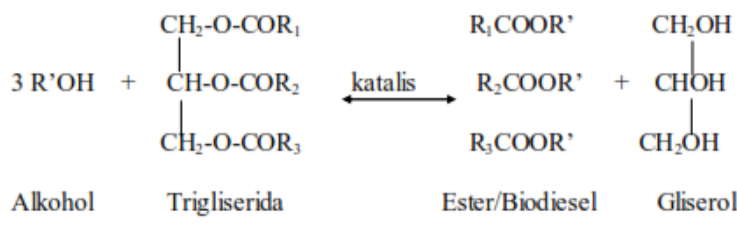

Kedua reaksi diatas baik esterifikasi dan transesterifikasi merupakan reaksi reversible yang menyebabkan konversi asam lemak menjadi produk akan sangat bergantung pada kesetimbangan reaksi. Sehingga jumlah alcohol atau reaktan berlebih.

Adsorben bahan alami adalah adsorben yang berasal dari bahan-bahan alami, seperti tumbuh-tumbuhan dan kayu. Adsorben ini dapat digunakan sebagai penjernih pada pemisahan minyak, terutama minyak jelantah, karena menggandung selulosa yang terdapat didalam adsorben yang berasal dari bahanbahan alami tersebut. Penggunaan serabut kelapa dan jerami padi sebagai adsorben dapat menurunkan bilangan asam (FFA) ${ }^{[6]}$.

Katalis secara umum berfungsi untuk meningkatkan kecepatan reaksi dalam membentuk produk yang diinginkan. Dalam proses pembuatan biodiesel $\mathrm{KOH}$ sebagai katalis basa homogen lebih mudah digunakan dan waktu yang diperlukan lebih cepat dan mudah pemisahannya dibanding dengan $\mathrm{NaOH}$. Suatu teknik pembuatan biodiesel hanya akan berguna apabila produk yang dihasilkannya sesuai dengan spesifikasi (syarat mutu) yang telah ditetapkan dan berlaku di daerah pemasaran biodiesel tersebut. Persyaratan mutu biodiesel di Indonesia sudah diberlakukan dalam SNI-04-7182-2006, dan direvisi pada SNI 7182:2015. Parameter yang menunjukan keberhasilan pembuatan biodiesel dapat dilihat dari flash point, pour point, kinematic viscosity, condradson carbon residu, air dan sedimen, dll. Terpenuhi semua persyaratan SNI 7182:2015 biodiesel menunjukan bahwa biodiesel tersebut tidak hanya telah dibuat dari bahan mentah yang baik, melainkan juga dengan tata cara proses serta pengolahan yang baik pula.

\section{METODOLOGI PENELITIAN 3.1 Bahan dan Alat Penelitian}

Bahan dan alat yang digunakan dalam penelitian ini adalah Hot plate, piknometer, viscometer Otzward, labu leher tiga, pengaduk, termometer, kondensor, separator, beaker glass, gelas ukur, neraca analitik, spatula, saringan serta alat analisis lainnya. Bahan yang digunakan adalah minyak kacang tanah bekas yang diambil dari pedagang sate, arang aktif, metanol, $\mathrm{KOH}$ dan asam sulfat, aquadest, $\mathrm{NaOH}$, indikator $\mathrm{PP}$ dan bahan kimia untuk analisis lainnya.

\subsection{Pretreatment}

Minyak kacang tanah yang didapatkan dari hasil proses pembuatan bumbu kacang sate. Minyak ini masih banyak terdapat impurities atau zat pengotor sehingga perlu dilakukan proses pemisahan minyak dari zat pengotor yang masih terdapat didalam minyak dengan metode pengendapan dilakukan untuk memisahkan partikel - partikel padatan dan air pada minyak kacang dengan memanfaatkan perbedaan berat jenis dan gaya gravitasi bumi menggunakan alat separator.

\subsection{Proses Adsorpsi}

Minyak kacang tanah yang telah dipisahkan dengan cara diendapkan masuk ke 
tahap adsorpsi yaitu Proses penyerapan yang bertujuan untuk mengurangi kandungan impurities (TSS dan air) serta asam lemak bebas dalam minyak kacang tanah.

\subsection{Analisa Asam Lemak Bebas Dengan Metode Titrasi Asam Basa}

Tahapan Analisa asam lemak bebas sebagai berikut:

1. Sampel ditimbang sebanyak 5 gram.

2. Sampel dimasukkan dalam erlenmeyer dan ditambahkan $50 \mathrm{~mL}$ alkohol netral.

3. Dipanaskan hingga mendidih.

4. Setelah sampel dingin ditambahkan dengan $2 \mathrm{~mL}$ indikator PP dan dititrasi dengan larutan $0,1 \mathrm{~N} \mathrm{NaOH}$ yang telah distandarisasi sampai warna merah jambu tercapai dan tidak hilang selama 30 detik.

\subsection{Preparasi Minyak Kacang, Metanol dan Katalis}

Minyak kacang tanah sebanyak $500 \mathrm{ml}$ dengan kandungan asam lemak bebas $>1 \%$, lalu metanol sebanyak $250 \mathrm{ml}$ dan katalis $\mathrm{H}_{2} \mathrm{SO}_{4} 1 \mathrm{M}$ sebesar $5 \% \mathrm{v}$ minyak kacang tanah lalu dilakukan pencampuran antara metanol dan $\mathrm{H}_{2} \mathrm{SO}_{4}$ sehingga membentuk senyawa metoksil.

\subsection{Proses Reaksi Esterifikasi}

Minyak kacang tanah dimasukkan kedalam reaktor lalu dipanaskan hingga suhu $50{ }^{\circ} \mathrm{C}$. Kemudian tambahkan metoksil yaitucampuran metanol $250 \mathrm{ml}$ dan katalis $\mathrm{H}_{2} \mathrm{SO}_{4} 5 \% \mathrm{v}$ minyak kacang tanah kedalam reaktor secara perlahan, setelah seluruh metoksil telah dialirkan kedalam reaktor. Atur suhu didalam reaktor sebesar $60{ }^{\circ} \mathrm{C}$ dan pengadukan dengan kecepatan $\pm 300 \mathrm{Rpm}$ selama 60 menit.

\subsection{Pengendapan dan Pemisahan}

Setelah dilakukan proses esterifikasi maka dihasilkan minyak (ester alkil) dan air. Untuk memisahkan antara minyak dan air perlu dilakukannya proses pengendapan dengan menggunakan separator. Kemudian minyak dan air dipisahkan sehingga dihasilkan minyak (ester alkil) yang memiliki kadar asam lemak bebas $<0,5 \%$.

\subsection{Preparasi Minyak Kacang, Metanol dan Katalis}

Minyak kacang tanah sebanyak $250 \mathrm{ml}$ dengan kandungan asam lemak bebas $<5 \%$, lalu metanol sebanyak $750 \mathrm{ml}$ dan katalis $\mathrm{KOH}$ yang di variabelkan yaitu $0,5 \% \mathrm{wt}, 1$ $\%$ wt, $1,5 \%$ wt, dan $2 \%$ wt kemudian dilakukan pencampuran antara metanol dan $\mathrm{KOH}$ sehingga membentuk senyawa metoksida.

\subsection{Proses Reaksi Transesterifikasi}

Minyak kacang tanah dialirkan kedalam reaktor lalu dipanaskan hingga suhu $50{ }^{\circ} \mathrm{C}$. Kemudian tambahkan metoksida yaitu campuran metanol sebanyak $750 \mathrm{ml}$ dan katalis dengan jumlah tertentu (variabel) kedalam reaktor secara perlahan, setelah seluruh metoksida telah dialirkan kedalam reaktor. Atur suhu didalam reaktor sebesar 60 ${ }^{\circ} \mathrm{C}$ dan pengadukan dengan kecepatan \pm 300 rpm selama 60 menit.

\subsection{Pengendapan dan Pemisahan}

Setelah dilakukan proses transesterifikasi maka dihasilkan minyak (biodiesel) + gliserol. Untuk memisahkan antara minyak (biodiesel) dan gliserol perlu dilakukannya proses pengendapan selama 1 hari lalu minyak (biodiesel) dan gliserol dipisahkan, sehingga dihasilkan minyak ester alkil (biodiesel). Untuk menghilangkan methanol dan $\mathrm{KOH}$ yang terikut pada biodiesel, maka dilarutkan dengan menggunakan aquadest pada suhu $\pm 50{ }^{\circ} \mathrm{C}$ sebanyak $250 \mathrm{ml}$, proses dilakukan sebanyak 4 kali pencucian untuk mendapatkan hasil biodiesel yang lebih baik.

\section{HASIL DAN PEMBAHASAN \\ 4.1 Proses Adsorpsi}

Proses adsorpsi menggunakan adsorben arang aktif dengan tujuan untuk menghilangkan kandungan air, padatan dan kandungan asam lemak bebas. Pada proses adsoprsi ini minyak kacang tanah direndam dengan arang aktif selama 1 hari agar partikel - partikel padatan dan air serta asam lemak bebas berkurang sehingga didapatkan nilai asam lemak bebas berkurang dari 1,28\% menjadi $1,09 \%$.

\subsection{Hasil Reaksi Esterifikasi Minyak Kacang Tanah}


Esterifikasi adalah tahap konversi dari asam lemak bebas menjadi ester. Esterifikasi mereaksikan minyak lemak dengan alkohol (metanol), selain itu juga ditambahkan katalis berupa asam kuat seperti asam sulfat yang bertujuan untuk mendorong agar reaksi dapat terkonversi dengan sempurna dan dapat menurunkan asam lemak bebas pada temperatur $60{ }^{\circ} \mathrm{C}$. Minyak kacang tanah yang sebelumnya telah di cek kadar asam lemak bebas (ALB), yaitu: $1,28 \%$ dengan menggunakan metode titrasi asam basa. Minyak yang diencerkan dengan alkohol, lalu dipanaskan hingga suhu mencapai $50{ }^{\circ} \mathrm{C}$. Selanjutnya minyak yang telah diencerkan dengan alkohol dititrasi dengan menggunakan indikator PP dan senyawa basa $\mathrm{NaOH} 0,5 \mathrm{~N}$ hingga minyak berwarna merah jambu. Terjadi penurunan ALB dari 1,28\% menjadi 1,09\% dengan adsorpsi dan setelah mengalami proses esterifikasi nilai ALB sebesar $0,45 \%$.

\subsection{Hasil Reaksi Transesterifikasi Minyak Kacang Tanah}

Transesterifikasi yang biasa juga disebut alkoholisis ialah tahap proses konversi dari trigliserida (minyak nabati) menjadi alkil ester melalui reaksi dengan alcohol sehingga terjadi perpindahan gugus alkil pada alkohol untuk membentuk metil ester dan gliserol yang menjadi produk samping. Pada proses ini trigliserida atau minyak nabati akan dikonversi menjadi metil ester asam-asam lemak (biodiesel). Minyak nabati dimasukkan terlebih daluhu kedalam reaktor sebanyak 500 $\mathrm{ml}$ panaskan hingga mencapai suhu $50{ }^{\circ} \mathrm{C}$ kemudian masukkan campuran metanol 1.500 $\mathrm{ml}$ dan $\mathrm{KOH}$ (metoksida), kemudian atur Heater plate pada suhu $60{ }^{\circ} \mathrm{C}$ dengan putaran sebesar $300 \mathrm{rpm}$. Proses ini dilakukan selama 1 jam, sebanyak empat kali percobaan dengan perbedaan konsentrasi katalis $\mathrm{KOH} \mathrm{0,5 \% wt,} 1$ $\%$ wt, 1,5 \%wt, dan $2 \%$ wt. Tujuannya untuk mengetahui kualitas biodiesel dari perbedaan konsentrasi katalis yang digunakan. Setelah sesuai dengan waktu yang diinginkan biodiesel dikeluarkan dari reaktor dan selanjutnya didinginkan terlebih dahulu dan didiamkan selama 1 hari sampai biodiesel dan gliserolnya berbentuk dua lapisan, lapisan atas biodiesel dan lapisan bawah gliserol. Kemudian pisahkan biodiesel dengan gliserol. Untuk menghilangkan metanol yang tidak bereaksi dengan minyak dan $\mathrm{KOH}$ yang terikut pada biodiesel maka dicuci dulu dengan air hangat suhu $\pm 50{ }^{\circ} \mathrm{C}$ sebanyak $500 \mathrm{ml}$, proses dilakukan sebanyak 4 kali pencucian untuk mendapatkan hasil biodiesel yang lebih baik, sehingga yang tersisa hanya biodiesel murni. Selanjutnya biodiesel dianalisa spesifikasinya.

\begin{tabular}{|c|c|c|c|c|c|c|c|}
\hline$\underset{\square}{\mathbb{2}} 0^{\circ}$ & 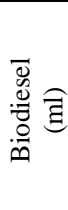 & 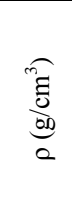 & 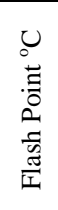 & $=\widehat{\overrightarrow{\tilde{s}}}$ & 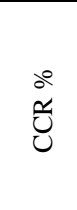 & 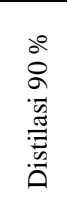 & 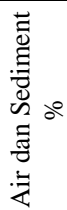 \\
\hline 0,5 & 390 & 0,881 & 130 & 7,23 & 0,112 & $91 \%$ & 0,09 \\
\hline 1 & 400 & 0,880 & 129 & 7,20 & 0,101 & $92 \%$ & 0,07 \\
\hline 1,5 & 420 & 0,875 & 126 & 7,07 & 0,098 & $92 \%$ & 0,04 \\
\hline 2 & 440 & 0,870 & 122 & 6,87 & 0,094 & $91 \%$ & 0,05 \\
\hline
\end{tabular}

\subsection{Pengaruh Variasi Konsentrasi Katalis Terhadap Rendemen Biodiesel}

Pada hasil reaksi untuk hasil biodiesel yang diperoleh pada setiap konsentrasi terjadi kenaikan perolehan rendemen biodiesel yang cukup signifikan. Semakin tinggi konsentrasi katalis yang digunakan maka semakin tinggi rendemen biodiesel yang diperoleh pada biodiesel.

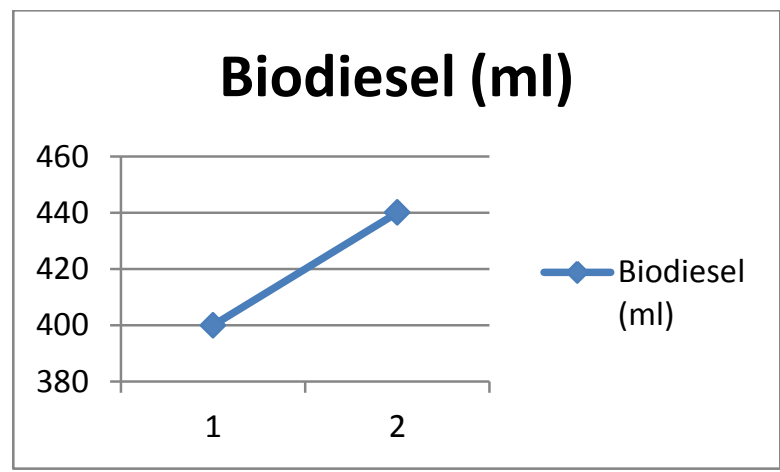

Gambar 4.1 Grafik Hasil Rendemen Biodiesel Terhadap Perbedaan Konsentrasi KOH 
Katalis $\mathrm{KOH}$ pada $0,5 \%$ wt $\mathrm{KOH}$ didapat rendemen biodiesel sebesar $390 \mathrm{ml}, 1$ \%wt KOH sebesar $400 \mathrm{ml}$ rendemen biodiesel, $1,5 \%$ wt sebesar $420 \mathrm{ml}$, dan pada konsentrasi $2 \%$ didapatkan rendemen sebesar $440 \mathrm{ml}$. Pada penambahan konsentrasi katalis hasil rendemen semakin besar, dikarenakan dengan semakin banyak katalis yang ditambahkan maka energi aktivasi yang diperlukan semakin menurun, sehingga jumlah molekul yang teraktifkan semakin besar dan menyebabkan laju reaksi menjadi naik.

\subsection{Pengaruh Variasi Konsentrasi Katalis Terhadap Densitas Biodiesel}

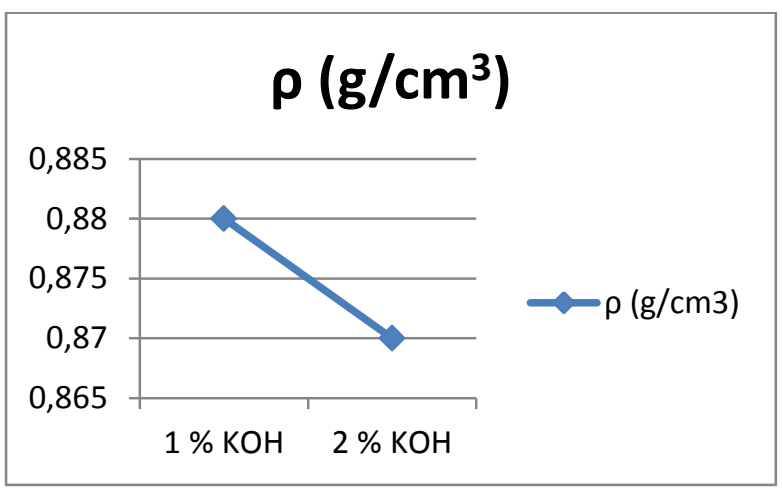

\section{Gambar 4.2 Grafik Densitas Biodiesel Terhadap Perbedaan Konsentrasi KOH}

Dari hasil reaksi untuk hasil biodiesel yang diperoleh pada setiap konsentrasi terjadi penurunan nilai densitas yang tidak terlalu signifikan. Semakin tinggi konsentrasi katalis yang digunakan maka semakin kecil nilai densitas yang diperoleh pada biodiesel, yaitu pada $0,5 \%$ wt $\mathrm{KOH}$ didapat densitas sebesar $0,881 \mathrm{~g} / \mathrm{cm}^{3}, 1 \%$ wt KOH sebesar $0,880 \mathrm{~g} / \mathrm{cm}^{3}$, $1,5 \%$ wt sebesar $0,875 \mathrm{~g} / \mathrm{cm}^{3}$, dan pada konsentrasi $2 \%$ didapatkan densitas sebesar $0,870 \mathrm{~g} / \mathrm{cm}^{3}$. Komposisi asam lemak dan kemurnian bahan baku mempunyai pengaruh terhadap densitas. Nilai densitas yang tinggi disebabkan oleh semakin pendeknya rantai karbon dan peningkatan jumlah ikatan rangkap pada asam lemak.

\subsection{Pengaruh Variasi Konsentrasi Katalis Terhadap Flash Point Biodiesel}

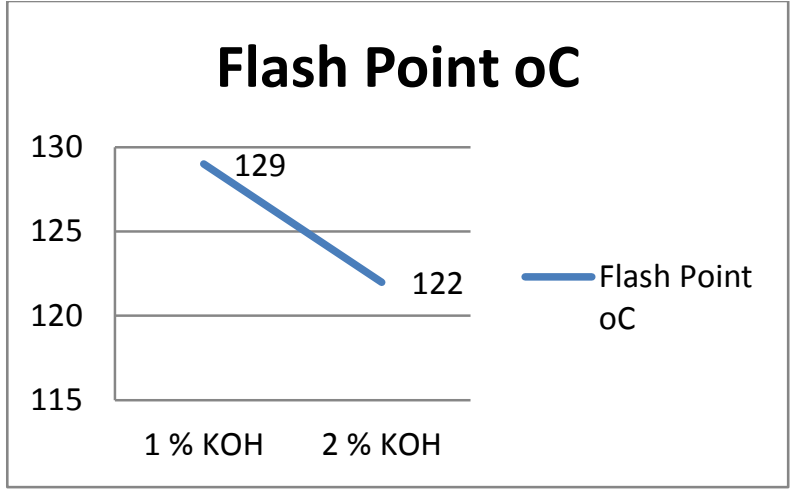

Gambar 4.3 Grafik Flash Point Biodiesel Terhadap Perbedaan Konsentrasi KOH

Pada hasil reaksi untuk hasil biodiesel yang diperoleh pada setiap variasi konsentrasi terjadi penurunan nilai flash point yang memiliki nilai range penurunan sebesar $1-4$ ${ }^{\circ} \mathrm{C}$. Semakin besar konsentrasi katalis yang digunakan maka nilai flash point juga akan semakin kecil, yaitu pada $0,5 \%$ wt $\mathrm{KOH}$ didapat flash point sebesar $130^{\circ} \mathrm{C}, 1 \% \mathrm{wt}$ $\mathrm{KOH}$ sebesar $129^{\circ} \mathrm{C}, 1,5 \%$ wt sebesar $126^{\circ} \mathrm{C}$, dan pada konsentrasi $2 \%$ didapatkan flash point sebesar $122^{\circ} \mathrm{C}$. semakin flash point rendah hal ini disebabkan karena rantai karbon asam lemak yang semakin pendek menyebabkan mudah menguap.

\subsection{Pengaruh Variasi Konsentrasi Katalis Terhadap Pour Point Biodiesel}

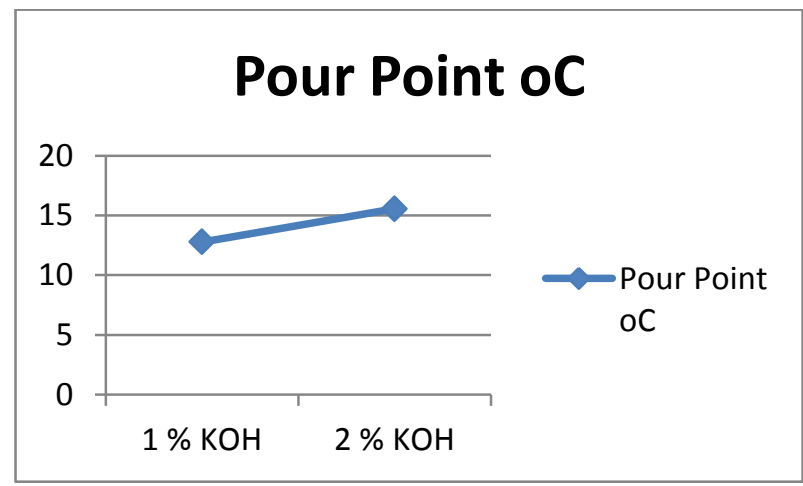

\section{Gambar 4.4 Grafik Pour Point Biodiesel} Terhadap Perbedaan Konsentrasi KOH

Dari hasil biodiesel yang diperoleh pada karakteristik pour point dengan nilai yang berbeda-beda. terjadi kenaikan titik tuang pada setiap variasi katalis. Pada 
konsentrasi katalis $\mathrm{KOH} 0.5 \%$ wt didapatkan $12,77{ }^{\circ} \mathrm{C}$, lalu pada $\mathrm{KOH} 1 \%$ wt diperoleh $13,88{ }^{\circ} \mathrm{C}$, kemudian pada $\mathrm{KOH} 1,5 \% \mathrm{wt}$ diperoleh $14,44{ }^{\circ} \mathrm{C}$ dan pada $\mathrm{KOH} 2 \%$ wt diperoleh $15,55{ }^{\circ} \mathrm{C}$. Sehingga pada variasi $\mathrm{KOH} 0,5 \%$ wt, yaitu $12,77{ }^{\circ} \mathrm{C}$ adalah yang terbaik. Kenaikan konsentrasi katalis berbanding lurus dengan temperatur pour point hal ini disebabkan oleh adanya katalis $\mathrm{KOH}$ yang mempengaruhi nilai pour point.

\subsection{Pengaruh Variasi Konsentrasi Katalis Terhadap distilasi 90\% Biodiesel.}

Dari hasil pengujian distilasi $90 \%$ pada biodiesel yang diperoleh dengan variasi konsentrasi katalis $\mathrm{KOH}$ diperoleh hasil $91 \%$ pada konstrasi $\mathrm{KOH} 0,5 \% \mathrm{wt}, 92 \%$ pada konsentrasi $\mathrm{KOH} 1$ \%wt, $92 \%$ pada konsentrasi $\mathrm{KOH} \mathrm{1,5 \% wt} \mathrm{dan} 91 \%$ pada konsentrasi $\mathrm{KOH} 2 \%$ wt. Pada hasil Distilasi $90 \%$ telah memenuhi standar SNI distilasi 90 $\%$ dengan temperatur maksimal $360{ }^{\circ} \mathrm{C}$ pada setiap kenaikan variasi konsentrasi $\mathrm{KOH}$ yang digunakan.

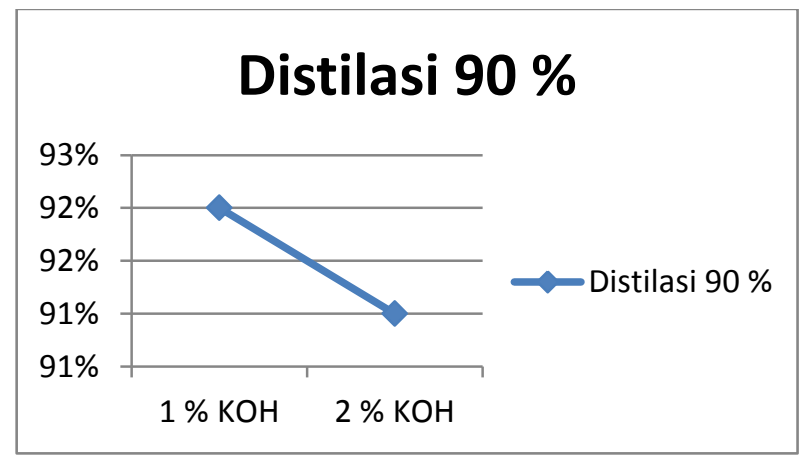

\section{Gambar 4.5 Grafik Destilasi $90 \%$ Biodiesel} Terhadap Perbedaan Konsentrasi KOH

\subsection{Pengaruh Variasi Konsentrasi Katalis Terhadap Air andS Biodiesel \\ Dari hasil pengujian air dan sediment} pada biodiesel yang diperoleh dengan variasi konsentrasi katalis $\mathrm{KOH}$ diperoleh hasil 0,09

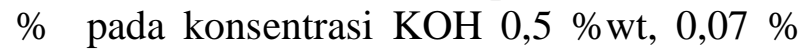
pada konsentrasi $\mathrm{KOH} 1 \%$ wt, 0,04 \% pada konsentrasi $\mathrm{KOH} 1,5 \%$ wt dan 0,05 \% pada konsentrasi $\mathrm{KOH} 2$ \%wt. Hal ini dikarenakan pada proses pemisahan menggunakan separator (corong pemisah) tidak terlalu baik sehingga kandungan air dan sedimen pada masih fluktuatif.

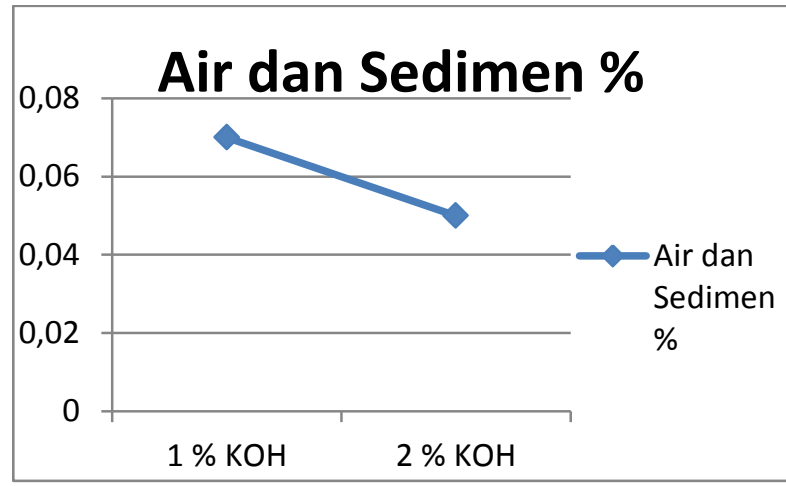

Gambar 4.6 Grafik Air dan Sediment Biodiesel Terhadap Perbedaan Konsentrasi KOH

\subsection{Pengaruh Variasi Konsentrasi Katalis pada Biodiesel Terhadap Uji Cooper Strip Corrosion}

Pada hasi uji Copper strip corrosion tidak ada perbedaan pada warna tembaga, nilai uji semua variasi katalis dalam pembuatan biodiesel adalah 1 .

\section{KESIMPULAN DAN SARAN \\ 5.1 Kesimpulan}

Dari pembahasan tersebut, maka kesimpulan dari penelitian ini, yaitu : Pada hasil rendemen biodiesel yang diperoleh dengan konsentrasi $\mathrm{KOH} 2$ \%wt adalah yang terbaik yaitu sebesar $440 \mathrm{ml}$. Dari hasil biodiesel yang diperoleh pada konsentrasi 2 $\%$ wt $\mathrm{KOH}$ padat adalah hasil yang optimal karena memenuhi spesifikasi standar biodiesel, kecuali pada viskositas kinematik sebesar 6,87 cSt dan residu karbon sebesar 0,094 \%wt.

\section{DAFTAR PUSTAKA}

Aziz, Isalmi, Siti Nurbayti dan Badrul Ulum. 2011. Pembuatan Produk Biodiesel dari Minyak Goreng Bekas Dengan Cara Esterifikasi dan Transesterifikasi. Jurnal Valensi Volume 2, No. 3, 443-448.

Budiman, Arif. dkk. 2014. Biodiesel Bahan Baku, Proses, dan Teknologi. Gadjah Mada University Press hal 33. 
Gerhard Knothe, Jurgen Krah, Jon Van Gerven. 2010. The biodiesel handbook 2nd edition, AOCS press Illinois hal. 1.

Hasbullah. 2001. Teknologi Tepat Guna Agro Industri Kecil Sumatera Barat. Dewan Ilmu Pengetahuan. Teknologi dan Industri Sumatra Barat.

Julius Fernando Pakpahan, Tomas Tambunan, Agnes Harimby dan M. Yusuf Ritonga 2013. Pengurangan FFA Dan Warna Dari Minyak Jelantah Dengan Adsorben Serabut Kelapa Dan Jerami. Jurnal Teknik Kimia USU.

Mushtaq Ahmad, Mir Ajab Khan, Muhammad Zafar, Shazia Sultana. 2013. Practical Handbook on Biodiesel Production and Properties. CRC PRESS London Newyork hal 127 
P-ISSN: 2089-5925 E-ISSN: 2621-9328

Antrant

Jurnal Teknik Patra Akademika

PATA

LII I 